\title{
Hypothetical versus Actual Support Providers in Comparative Network Research
}

\author{
Valentina Hlebec ${ }^{1}$ and Tina Kogovšek ${ }^{2}$
}

\begin{abstract}
Informal social networks are the most important source of social support, which is an essential foundation for the quality of everyday life. Distributions of various types of social networks have to be studied from a comparative perspective to evaluate the effects of the change in political, social and economic systems in Slovenia on social network composition and structure. Data from two studies are compared: one made before (1987) and one after the transition (2002) on representative samples of adult residents of Slovenia. In the paper the ability of informal social networks to provide an adequate sources of social support is discussed as the substantive part of this research. The effects of characteristics of the measurement instruments (hypothetical versus actual support providers) on obtained estimates of network composition are presented and evaluated. The advantages and disadvantages of the relationship approach to measuring personal networks are discussed with regard to complete evaluation of network membership.
\end{abstract}

\section{Introduction}

In measuring social support provision, two general approaches can be distinguished. A simple way to evaluate provision of social support is to ask an ordinary survey question where response categories are types of support providers (e.g., partner, parents, children, friends, etc.). This approach is appealing, as it saves time and money. However, information obtained by this approach is limited.

Most often, when evaluating social support provision, the social network approach is used. The list of egos (respondents) is obtained in the first step. In the second step, existing ties are identified - all alters with whom the focal ego has some sort of relationship. The list of alters is collected with a survey question called a name generator. When all ties have been identified, the contents of ties and their characteristics are assessed. In most cases the characteristics of

\footnotetext{
1 University of Ljubljana, Faculty of Social Sciences, Kardeljeva pl. 5, 1000 Ljubljana, Slovenia; Valentina.Hlebec@guest.arnes.si

${ }^{2}$ University of Ljubljana, Faculty of Social Sciences, Kardeljeva pl. 5, 1000 Ljubljana, Slovenia; Tina.Kogovsek@guest.arnes.si
} 
alters are also measured. The name generator approach yields more data, which is also of higher quality. However, it is time and money consuming, and it requires either considerable effort from the respondent, when it is applied in selfadministered mode (e.g., see Lozar et al., 2004) or by complex coordination between interviewer and respondent, when it is applied through personal interviews (e.g., Kogovšek et al., 2002).

Let us consider, which information can be obtained more specifically with each approach. With the role-relation approach, unique identification of persons is possible only for "unique" role-relations, such as partner. ${ }^{3}$ With other rolerelations, multiple actual persons cannot be distinguished (e.g., friends, children or siblings). If we regard each possible role relation functionally, this approach poses no particular limitation. However, estimation of the network composition, a frequent practice in social network analysis, is limited, since we do not possess information about the number of children, siblings and so on. Thus, the proportion of different types of relationships (e.g., whether the personal network is primarily kin- or friend-oriented) cannot be estimated. Therefore, the only information we can obtain with both approaches is what type of role relation is the most frequent for various provisions of social support across groups of respondents.

The research questions raised in this paper came to our attention when we considered two studies that differed in terms of the two specified approaches for measuring social support provision. The aim of the research project of which this paper is a part of was to evaluate the changes in social support providers for residents of Slovenia over a longer period of time, and to establish whether and to what extent the change in the social, political and economic system played a part in those changes. The purpose of the study was to analyze the existing secondary data on social support provision, collected in 1987 and 2002, that is, before and after the change in the system at the beginning of the 90s. However, those data were collected for different purposes and using a different methodology, as described in the following paragraph.

In both studies Burt's name generator ${ }^{4}$ (Burt, 1984) was applied. Several other questions regarding social support provision were also asked in the two surveys, the most important difference being that they were asked using two different approaches (the role relation approach in 1987 and the name generator approach in 2002) and using two different wordings (hypothetical and usual providers). Therefore, the aim of this paper is to explore the methodological aspects of using such different data sources for comparative social network research, to find out which comparable data can be obtained for further analysis, and to test the variability of two question wordings - actual and hypothetical.

\footnotetext{
${ }^{3}$ At least theoretically, though in reality, people could also have ex-partners in mind.

${ }^{4}$ There were several differences in the question wording of this name generator; this issue has been reported, analyzed and discussed elsewhere (Kogovšek and Hlebec, 2005, this volume of Metodološki zvezki).
} 
Furthermore, as a substantive part of the paper, we will observe Slovenian society at two points in time. Considering political events and changes in the socio-economic system in the period of time that is relevant to our study (19872002), we can say that this is the transition period from a communist regime to a democratic system and from a state regulated economy to a market economy. Several changes were introduced in the social and health security systems. However, national reports on development in Slovenia (e.g., Hanžek, 1998, 1999; Javornik and Korošec, 2003) claim that increasing social and economic inequalities as the result of the transition have a greater effect on the differences in health and overall well-being than the health security system itself, which remained relatively widely available to all people. In this paper we focus on social support provision from informal sources, i.e. ego-centered social support networks, which are an important foundation for the quality of everyday life. We would like to find out whether changes in the socio-economic system are reflected in and accompanied by changes in social support providers. At this point in our research the substantive results are an initial and descriptive analysis that is to be followed by a deeper interpretation of the phenomena under study. On the other hand, the substantive analysis is also relevant to the discussion of (potential) methodological effects, that is, to a consideration of which effects are more relevant in accounting for the differences between the two years - methodological or broader social effects (i.e., the transition from a communist to a modern democratic system).

\section{Description of the 1987 and 2002 Studies}

In this section, the original 1987 and 2002 studies are briefly ${ }^{5}$ described. Two cross-sectional studies (1987 and 2002) include data on the personal support networks of the residents of Slovenia (Boh et al., 1987a $\mathrm{a}^{6}$; Ferligoj et al., 2002 ${ }^{7}$ ). These studies differ in many characteristics:

- Sample size: 289 in 1987 and 5013 in 2002;

- Interview mode: face-to-face interviews (partly self-administered) in 1987 and computer-assisted telephone interviews in $2002 ;^{8}$

\footnotetext{
${ }^{5}$ More detailed description is available elsewhere (Kogovšek and Hlebec, 2005).

${ }^{6}$ Boh, Katja et al. Stratifikacija in kvaliteta življenja v Jugoslaviji 1987 [kodirna knjiga]. Ljubljana.Univerza v Ljubljani. Institut za sociologijo in filozofijo pri Univerzi v Ljubljani, 1987. Ljubljana. Univerza v Ljubljani. Arhiv družboslovnih podatkov [izdelava, distribucija], 2000.

${ }^{7}$ Ferligoj, Anuška et al. Omrežja socialnih opor prebivalstva Slovenije. 2002 [kodirna knjiga]. Ljubljana: Fakulteta za družbene vede in Inštitut Republike Slovenije za socialno varstvo.

${ }^{8}$ For a thorough discussion of the differences between face-to-face and telephone interviews in collecting social network data and an analysis of the reliability and validity of such data, see Kogovšek et al. (2002); Hlebec and Kogovšek (2005).
} 
- Age of respondents: in 1987 the lower age limit was 15 and the upper age limit was 75, and in 2002 data were collected only on respondents 18 and over, with no upper limit.

Regardless of these differences, both studies give basic information about various support provisions. Both surveys provide representative samples of the Slovenian adult population after weighting. In both surveys several social support provisions were assessed, namely minor material aid, social support in the case of illness, financial support, emotional support in the case of trouble with a partner and in the case of sadness or depression, and advice support. However only two social support provisions were comparable across the studies, apart from the Burt's name generator. The characteristics of the survey questions used to measure these comparable support dimensions are presented in Table 1.

Table 1: Differences between indicators in two studies.

\begin{tabular}{|c|c|c|}
\hline Indicator/Study & $\begin{array}{c}\text { The Stratification and Level of } \\
\text { Living Survey in Yugoslavia, } \\
1987\end{array}$ & $\begin{array}{l}\text { Social Support Networks of } \\
\text { Residents of Slovenia, } 2002\end{array}$ \\
\hline $\begin{array}{l}\text { Discussion } \\
\text { partners }\end{array}$ & $\begin{array}{c}\text { Name generator, } \\
\text { Actual interactions, } \\
\text { Time limitation, } \\
\text { Reduced to the first two support } \\
\text { providers }\end{array}$ & $\begin{array}{l}\text { Name generator, } \\
\text { Actual provision, } \\
\text { Usual providers } \\
\text { Reduced to the first two } \\
\text { support providers }\end{array}$ \\
\hline $\begin{array}{l}\text { Support in the } \\
\text { case of an illness }\end{array}$ & $\begin{array}{l}\text { Role relation approach, } \\
\text { Hypothetical question, } \\
\text { The first and the second } \\
\text { provider }\end{array}$ & $\begin{array}{l}\text { Name generator, } \\
\text { Actual (usual) provision, } \\
\text { Reduced to the first two } \\
\text { support providers }\end{array}$ \\
\hline $\begin{array}{l}\text { Financial } \\
\text { support }\end{array}$ & $\begin{array}{l}\text { Role relation approach, } \\
\text { Hypothetical question, } \\
\text { The first and the second } \\
\text { provider }\end{array}$ & $\begin{array}{l}\text { Name generator, } \\
\text { Hypothetical question, } \\
\text { Reduced to the first two } \\
\text { support providers }\end{array}$ \\
\hline
\end{tabular}

Items for measuring financial support and support in the case of illness were used in both years. However, in 1987 the role-relationship approach was used. Respondents provided the first and the second most important role relation (e.g., father, sister, best friend), to whom he/she turned for help. In 2002 the name generator approach was used. Respondents first provided the names of the persons for each type of support, and the role relationships of these persons were described later in the name interpreter questions. In both years we obtained similar information on the respondent's type of relationship towards the support provider. However, different measurement instruments can affect responses. Additionally, support in the case of an illness was measured hypothetically in 1987, whereas in 2002 we measured persons to whom the respondents usually turned for help. The 2002 data from the network generator approach was reduced to the first and 
second provider of social support, and only data about the type of support provider was taken into account. In both studies the Burt's name generator was used. The data obtained by this approach was reduced to information obtained by the rolerelation approach (information about the role relation of the first and the second named alters is analyzed). There are several variations in measurement instruments, and in the following section some possible effects of the question wording ("hypothetical" versus "actual" support provision) on support providers are evaluated.

Table 2: Differences in two question wordings for support dimensions ${ }^{9}$

\begin{tabular}{|c|c|c|c|c|c|}
\hline Support dimension & Partner & Parents & Child & Siblings & Friend \\
\hline \multicolumn{6}{|l|}{ Discussion partners } \\
\hline First provider & $51 \%$ & $10 \%$ & $6 \%$ & $4 \%$ & $29 \%$ \\
\hline Second provider & $8 \%$ & $18 \%$ & $21 \%$ & $14 \%$ & $40 \%$ \\
\hline \multicolumn{6}{|l|}{ Material support } \\
\hline First provider & $42 \%$ & $24 \%$ & $14 \%$ & $14 \%$ & $6 \%$ \\
\hline Second provider (usual) & $14 \%$ & $32 \%$ & $33 \%$ & $14 \%$ & $7 \%$ \\
\hline $\begin{array}{r}\text { Second provider } \\
\text { (hypothetical) }\end{array}$ & $3 \%$ & $35 \%$ & $22 \%$ & $12 \%$ & $29 \%$ \\
\hline \multicolumn{6}{|l|}{$\begin{array}{l}\text { Support in the case of an } \\
\text { illness }\end{array}$} \\
\hline First provider & $46 \%$ & $29 \%$ & $15 \%$ & $6 \%$ & $3 \%$ \\
\hline Second provider (usual) & $16 \%$ & $34 \%$ & $35 \%$ & $10 \%$ & $6 \%$ \\
\hline $\begin{array}{r}\text { Second provider } \\
\text { (hypothetical) }\end{array}$ & $1 \%$ & $35 \%$ & $28 \%$ & $16 \%$ & $20 \%$ \\
\hline \multicolumn{6}{|l|}{ Financial support } \\
\hline First provider & $27 \%$ & $47 \%$ & $10 \%$ & $10 \%$ & $7 \%$ \\
\hline Second provider & $12 \%$ & $39 \%$ & $14 \%$ & $12 \%$ & $24 \%$ \\
\hline \multicolumn{6}{|l|}{$\begin{array}{l}\text { Discussing problems with } \\
\text { partner }\end{array}$} \\
\hline First provider (usual) & $23 \%$ & $4 \%$ & $20 \%$ & $14 \%$ & $39 \%$ \\
\hline First provider (hypothetical) & $7 \%$ & $11 \%$ & $11 \%$ & $13 \%$ & $58 \%$ \\
\hline Second provider (usual) & $0 \%$ & $26 \%$ & $21 \%$ & $12 \%$ & $41 \%$ \\
\hline $\begin{array}{r}\text { Second provider } \\
\text { (hypothetical) }\end{array}$ & $5 \%$ & $12 \%$ & $12 \%$ & $12 \%$ & $59 \%$ \\
\hline \multicolumn{6}{|l|}{ Talk to in case of sadness } \\
\hline First provider & $39 \%$ & $8 \%$ & $11 \%$ & $4 \%$ & $38 \%$ \\
\hline Second provider & $10 \%$ & $18 \%$ & $18 \%$ & $11 \%$ & $43 \%$ \\
\hline \multicolumn{6}{|l|}{$\begin{array}{l}\text { Asking for advice at major } \\
\text { life change }\end{array}$} \\
\hline First provider & $53 \%$ & $19 \%$ & $7 \%$ & $6 \%$ & $15 \%$ \\
\hline Second provider & $4 \%$ & $27 \%$ & $28 \%$ & $9 \%$ & $32 \%$ \\
\hline
\end{tabular}

\footnotetext{
${ }^{9}$ Only main answer categories are presented. Differences in question wordings are presented if significant.
} 


\section{Description and results of question wording experiment}

An experiment was designed to assess whether differently worded survey questions about social support ("hypothetical" versus "actual" support provision) result in significant differences in support providers. The test was done on data collected by 34 students from the Social Network Analysis course at the Faculty of Social Sciences in Ljubljana during the winter semester 2004/05. Apart from him/herself, each student interviewed four more persons. Since it is a convenience sample, the findings cannot be generalized to the general population. However, since the age and gender of the respondents were to a certain degree controlled, ${ }^{10}$ some tentative conclusions regarding this particular difference in question wording can be reached. The total sample size was 170 respondents, $42 \%$ male and $58 \%$ female. The majority of respondents was either married (37\%), living as married $(24 \%)$, or single $(29 \%)$. The educational level of respondents was skewed toward higher education (9\% elementary school, 69\% high school, and $23 \%$ college or more). The age of respondents was somewhat skewed towards younger respondents (42\% of age $18-29,28 \%$ of age $30-49$ and $30 \%$ of age 50 and over) if we compare this convenience sample with 2002 census data.

Apart from Burt's name generator, several questions about social support provision ${ }^{11}$ were asked, using the role relation approach in an experiment with usual and hypothetical providers. Results are presented in Table 2. The two wordings are compared across all support questions for the first and the second provider. ${ }^{12}$ Percentages for both question wordings are presented in the table only if the differences were statistically significant; otherwise we present the total percentages for both wordings together.

Four out of the seven questions were insensitive to changes in question wording (questions for assessing discussion partners, providers of financial support, people one talks to if feeling sad or depressed and people one asks for advice about a major life change). Two questions showed significant differences for the second support provider - the questions for assessing material support providers, and those for support providers in the case of an illness. Only one question showed significant variation in the percentage of most important providers of social support, i.e., the question for assessing the people to whom one talks when having trouble with one's partner. Explanations for such results should take into account three dimensions. Firstly, the support dimension should be

\footnotetext{
${ }^{10}$ Each student had to choose the other four persons from different age groups and follow a 50:50 gender distribution.

${ }^{11}$ Exact wording is in the Appendix.

12 Further analysis across demographical characteristics is not possible, as we have a small number of cases and five main response categories for social support. The majority of frequencies across cells in contingency tables would have expected a count less than 5 .
} 
considered, since different types of social support are provided by different others (they vary in closeness, importance, intensity and frequency of contacts). Secondly, the difference between the first and the second provider should be accounted for, since significant variation was more often obtained for the second provider. Thirdly, the question about the people to whom one talks when having trouble with one's partner was put to respondents who actually had partners as well as to respondents who currently did not have a partner.

Let us first discuss various providers of social support. From previous research on social networks and support provision, it is known (Fischer, 1982; Wellman et al., 1988; Wellman and Wortley, 1990; van Tilburg, 1990b) that practical help or material assistance is quite specialized. Special providers are responsible for different types of material aid: e.g., neighbors provide household upkeep; relatives and friends provide help around the house. Strong ties provide mostly emotional aid, minor services and companionship. Between parents and adult children it is mostly financial and emotional aid that is exchanged, together with large and small services. Immediate kin provide financial aid and major services. Physically accessible ties provide small and large services. Women tend to provide more diverse support activities than men, but are mostly in charge of emotional support. Similar findings were obtained in Slovenia (Iglič, 1988, Dremelj, 2003; Hlebec, 2003; Kogovšek et al., 2003).

Strong ties are therefore responsible for multiple support functions and are in this sense subject to variability. For example, the partner is a source of many support functions, and respondents who are very close to their partners tend to name the partner for many support provisions. On the other hand, some services are provided by convenient support providers such as: physically accessible ties, relatives who are called upon for provision of services regardless of their real closeness to the respondent, because of a blood tie, or friends who are tapped for various support provisions because they are trustworthy. It my happen that someone turns for various support provisions to friends in general, but when asked about it specifically, other providers had been used on the last few occasions. This reason can account for some variability in hypothetical vs. actual support providers.

Also, the maximum number of actual support providers should be discussed for various support dimensions. Some research in Slovenia (Hlebec, 2004) shows that people older that 50 would have only one provider on average for financial support and one or two providers on average for small and large aid, emotional support and support in the case of an illness. Therefore, for the types of support provisions where very strong ties are used and the number of actual support providers is small, there should be no significant differences between hypothetical and actual wordings. Emotional support in the case of depression, financial support, asking for advice about a major life change, and discussion partners are the support functions, that meet where both criteria. 
There are two cases where significant differences in the percentages for main support providers are found for the second provider, but not for the first provider, namely material support and support in the case of an illness. In both cases the category "friend" gains a larger percentage for the hypothetical question, and the category "partner" receives a smaller percentage for the hypothetical question. There are at least two plausible explanations. There is more than one support provider for such support, and respondents vary their answers (friend, partner) depending on the last few occasions, when such support was received. The second explanation follows the argument that people are cognitive misers, who search for the first satisfying answer (satisficing) rather than for the optimal answer (optimizing) and give the first answer that pops into their heads instead of the most accurate answer (Bodenhausen and Wyer, 1987, Hastie, 1987, Krosnick, 1991). It may be the case that the hypothetical wording stimulates a satisficing instead of an optimizing response strategy in situations where support providers have not precisely been determined or are interchangeable. This phenomenon is more probable at the end of the questionnaire, when the respondent is already tired and wants to finish the interview as soon as possible.

Explanations of significant differences for the first and the second provider of support in the case of trouble with a partner are twofold. One possibility is that people who do not have partners but were asked to provide an answer take this question very lightly and give a more satisficing answer. This answer could fall into the category of "friend", as this category receives $20 \%$ more responses for the hypothetical wording. Respondents with partners would give a similar answer but perhaps not as frequently. When actual support is evaluated, other response categories would receive more responses, depending on the actual situations.

Only three of the seven described support provisions were used in further analysis (discussion of important matters, help in the case of an illness and financial support). Since significant differences were found for the second provider of social support in the case of an illness, substantive analysis is limited only to the first provider of social support for all three dimensions.

\section{Substantive changes in support provision in Slovenia}

The characteristics of relationships in terms of their capacity to provide exchange of social support differ along several dimensions. Specific types of relationships provide different kinds of social support, depending on the characteristics of the ties themselves, such as the degree of intimacy, or strength, as well as on environmental factors such as physical proximity. However, close and intimate 
$\operatorname{ties}^{13}$ are the most important providers of various kinds of social support. Their multi-functionality points out the important role played by close ties in providing crisis support (Laireiter and Baumann, 1992). Vaux (1988: 28-29) states that support networks, i.e., social support network resources, are assumed to be stable in terms of size and composition, except in times of developmental transitions or non-normative life changes. In his analysis of changes in discussion network composition, Burt (1991) distinguished several age groups that are related to life changes such as getting a job, getting married and starting a family, or retiring). Other empirical evidence strongly supports his findings (Vaux, 1988; Wellman, 1979; Marsden, 1987; van der Poel, 1993; Kogovšek et al., 2003). For younger respondents (18-24), parents and friends are a very important source of social support, which is supplemented (25-30) by partners and co-workers. In later age categories (31-36), the percentage of parents decreases and is replaced (37-46) by siblings and children. For older adults (47-52), differentiation between weak and strong ties is less emphasized, parents disappear from the networks, while the percentage of co-workers decreases (53-60) and later disappears (61-66). Family members become more important, and ties with neighbors are revived (67 and over). Earlier research on discussion networks in Slovenia (Iglič, 1988) showed that discussion networks were small (2.99 alters on average) and mostly family oriented (1.87 alters on average were relatives). Recent research about social support networks of residents of Slovenia shows (Dremelj, 2003; Dremelj et al., 2004 ) that family members comprise about $60 \%$ of social support networks, friends about $20 \%$, co-workers about $5 \%$ and neighbors about $10 \%$. It seems that, regardless of the changes in the socio-economic system in Slovenia, the family orientation of support networks is permanent. However, no thorough comparison involving social support provision has been done until now, and we aim to explore what changes in social support provision, if any, have accompanied changes in the socio-economic system in Slovenia.

Firstly, the demographic characteristics ${ }^{14}$ of both studies are presented in Table 3. There are some differences across age and gender that are not significant; however, there are significant changes in the distribution of education, indicating that there are fewer people with lower education and more with higher education in 2002. This change in the educational level is not country specific, as educational level is rising in other European countries as well (e.g., Hanžek, 1998, 1999).

${ }^{13}$ Strong ties tend to provide a range of social support functions in general, whereas weaker ties tend to be specialized. Weak ties are nevertheless important in their capacity to provide access to heterogeneous sources, as opposed to strong ties which usually connect two similar individuals (Granovetter, 1982). Weak ties also differ from strong ties in their expectations of reciprocity in supportive exchange (Wellman et al., 1988). For weak ties, immediate or short term reciprocity in support exchange is expected. For strong ties, exact and short term reciprocity is not an expectation. However, in the long run, exchange within the overall ego-centered network tends to be in balance.

${ }^{14}$ The analysis is done on weighted data. 
Table 3: Demographic characteristics of both studies.

\begin{tabular}{|c|c|c|c|c|c|}
\hline \multicolumn{6}{|c|}{ Age categories } \\
\hline Study & $18-24$ & $25-34$ & $35-49$ & $50-64$ & $65-75$ \\
\hline SLLSY 1987 & 17 & 21 & 26 & 21 & 15 \\
\hline SSNRS 2002 & 13 & 19 & 30 & 24 & 14 \\
\hline \multicolumn{6}{|c|}{ Gender } \\
\hline Study & Male & Female & & & \\
\hline SLLSY 1987 & 46 & 54 & & & \\
\hline SSNRS 2002 & 48 & 52 & & & \\
\hline \multicolumn{6}{|c|}{ Education $^{15}$} \\
\hline Study & Elementary s. or less & $\begin{array}{c}\text { Vocational } \\
\text { school }\end{array}$ & $\begin{array}{l}\text { High } \\
\text { school }\end{array}$ & $\begin{array}{l}\text { College and } \\
\text { more }\end{array}$ & \\
\hline SLLSY 1987 & 58 & 13 & 23 & 7 & \\
\hline SSNRS 2002 & 30 & 28 & 29 & 12 & \\
\hline
\end{tabular}

Table 4: Three main providers of social support.

\begin{tabular}{rccc}
\hline \multicolumn{1}{ll}{ Illness } & & & \\
\hline SLLSY 1987 & Partner 52\% & Parents 23\% & Child 14\% \\
SSNRS 2002 & Partner 41\% & Child 18\% & Parents 14\% \\
\hline Discussion partner & & & \\
\hline SLLSY 1987 & Partner 24\% & Friend 20\% & Co-worker 16\% \\
SSNRS 2002 & Partner 39\% & Friend 26\% & \\
\hline Financial support & & & \\
\hline SLLSY 1987 & Parents 39\% & Partner 21\% & Child 14\% \\
SSNRS 2002 & Friend 26\% & Parents 23\% & Siblings 14\% \\
\hline
\end{tabular}

The three most frequent types of providers of social support across both years are presented in Table 4. Social support in the case of an illness is provided by the same types of support providers in both years. There is a change in the rating of these types and in the total percentage of both together. In 1987 for more than half of the respondents the most important support provider in the case of an illness was the partner, followed by parents for nearly a quarter of the respondents and by children (14\%). Altogether they provide social support for nearly $90 \%$ of respondents. In 2002 a partner is still the most important provider of social support in the case of an illness for $41 \%$ of the respondents, followed by children and parents. These three categories account for $73 \%$ of the respondents. The next most frequent category is the category of friend (10\%). We can say that there is a dispersion of sources in 2002, which can be explained in different ways. The SLLSY 1987 questionnaire the focus was on household tasks and shopping; the SSNRS 2002 questionnaire focused on help outside the household (shopping for groceries and medicine). Differences in percentages should therefore be interpreted with caution as to methodological and substantive factors.

\footnotetext{
${ }^{15}$ Differences are statistically significant $\left(\chi^{2}=99,27, p=0.000\right)$
} 
Discussion partners have changed across the years. In 1987 the most important discussion partners were a partner, friend and co-worker and they were about equally frequent. In 2002 a partner is the most important discussion partner for nearly $40 \%$ of respondents. Friends also received a larger percentage than in 1987 (20\% vs. $26 \%$ ). Among other categories, none received more than $8 \%$. One can say that discussion resources had shrunk in 2002 in comparison to 1987. There are fewer partners in 2002, yet at the same time the remaining partners are close and intimate others (partner and friends). These changes can be explained by the ever increasing work demands of the capitalist system, whereby people work longer hours and have less time for meeting others and discussing things outside job and family (e.g., Gregorčič in Hanžek, 2001). If this were the only reason, then coworkers would be quite a frequent discussion category among the age group that is the most active, which is not the case, as we will see later. On the other hand, family has been among the most important values in Slovenia for a long period of time. ${ }^{16}$

Perhaps the discussion topics were radically different in 2002 than in 1987. However, Bailey and Marsden (1999) used qualitative methods to study the effect of the context of the questionnaire on the response patterns to the Burt name generator. They found that varying the content of the preceding questions (politics and family) significantly affected the interpretation of "important matters", but not the network composition. However, despite the fact that the Burt network generator in the 1987 study followed a series of questions on political participation and a material support network generator in the 2002 study, we believe that context may have had some effect on the interpretation of "important matters", but not on the network composition. One plausible explanation is the following: the period around 1987 was about 5 years before Slovenian independence, and some political turmoil had already begun, people were more open to others outside the family and circle of friends and discussed matters that were quite important at the time. In this case, the interpretation of important matters could also have affected the selection of discussion partners.

Providers of financial support have changed as well. The most frequent providers of financial support in 1987 were parents (39\%), partner (21\%) and children (14\%). Altogether they account for $74 \%$ of respondents. We can say that these providers are all immediate family and that in 1987 the immediate family could provide financial support to its members. Financial support providers are different in 2002. The most frequent support providers are friends (26\%), followed

\footnotetext{
${ }^{16}$ For instance, in representative Slovene Public Opinion surveys over the last few years (e.g., Toš et al., 2002, 2003) a large percentage of respondents absolutely trusted family and kin $(53.6 \%$ in 2002, 61\% in 2003; moreover, further $34.5 \%$ in 2002 and $30.3 \%$ in 2003 trusted a lot). Most other categories (e.g., neighbors, church and priests, politicians, institutions) were trusted far less ( $20 \%$ or fewer responses in the "absolutely trust" category). Family is very important for $91.5 \%$ of respondents (Toš et al., 2004), whereas friends, as the next most important category, are very important for "only" $54.6 \%$ of respondents.
} 
by parents $(23 \%)$ and siblings (14\%). Although parents are among the most important providers of financial support, they receive about half the choices that they did in 1987. It seems that immediate family cannot provide financial support for family members anymore and that respondents have to seek it in other close ties such as friends. The three most frequent support providers account only for two thirds of respondents. It seems that transition to the capitalist system increased economic inequality and increased differences between people (e.g., Hanžek, 1998, 1999; Javornik and Korošec, 2003) and that the majority of respondents have to seek financial support outside the immediate family. In the SLLSY questionnaire, formal sources such as banks, state programs, work organizations, were offered. In the SSNRS 2002 data, where the name generator approach was used, only in formal providers were allowed, and the category of "friends" received the largest proportion.

Additionally, the social quality approach, used in analysis by Mandič et al. (2004), opens up a wealth of questions about various properties of the Slovenian society. Their analysis of Slovenia as a country in transition emphasizes that, with regard to socioeconomic security, there is diversity among the chosen domains when we observe the balance between individualisation and collectivisation of risk after the departure from the socialist, highly collectivist pattern of institutionalisation of welfare. In some domains, most notably in the system of social protection and basic income maintenance, a relatively efficient functioning of collective provision against individual income risk was preserved; »social protection « is definitely a »survivor « of the turbulent post-socialist reforms aimed at greater liberalisation. In other domains, such as health care, employment and education, some changes have been implemented towards individualisation of risk. In housing, however, the liberalisation went much farther very far and institutionally, the shift of risk towards individuals was extreme. The outcome of the transition, when measured by indicators of social quality, seems to be ambiguous. In some domains, such as employment and direct democracy, the legacy seems to have been preserved and even upgraded relative to the new circumstances. In others, most notably in public policy, consultative democracy and at the community level, there seems to be a significant »democratic deficit «.... (Mandič et al., 2004).

An overview along two demographic variables should give us insight into what is going on in various population groups. Differences across gender are presented in Table 5. Men have the same providers of social support in the case of an illness; however, these two providers (partner and parents) account for $80 \%$ of respondents in 1987 and for $63 \%$ of respondents in 2002. Women also have the same types of providers in both years (in 2002 parents are the third most frequent category $13 \%$ ) and they account for $90 \%$ of respondents in 1987 and for only $57 \%$ of respondents in 2002. The dispersion in support sources in the case of an illness and probable explanations for this trend were outlined in previous paragraphs. It is worth mentioning that gender differences reflect the traditional division of labor in 
the family, where women are primary care givers. Changes over time sustained traditional gender roles (partners provide support in the case of an illness for only $35 \%$ of female respondents in 2002, compared to $46 \%$ in 1987).

Table 5: Most important providers of social support and gender.

\begin{tabular}{|c|c|c|}
\hline Gender & Male & Female \\
\hline \multicolumn{3}{|l|}{ Illness } \\
\hline \multirow[t]{2}{*}{ SLLSY 1987} & Partner $57 \%$ & Partner $46 \%$ \\
\hline & Parents $23 \%$ & $\begin{array}{c}\text { Parents } 24 \% \\
\text { Child 20\% }\end{array}$ \\
\hline \multirow[t]{2}{*}{ SSNRS 2002} & Partner $48 \%$ & Partner $34 \%$ \\
\hline & Parents $15 \%$ & Child 23\% \\
\hline \multicolumn{3}{|l|}{ Discussion partner } \\
\hline \multirow[t]{3}{*}{ SLLSY 1987} & Neighbor $21 \%$ & Partner $31 \%$ \\
\hline & Co-worker $20 \%$ & Friend $23 \%$ \\
\hline & Partner, friend $17 \%$ & \\
\hline \multirow[t]{2}{*}{ SSNRS 2002} & Partner 52\% & Friend, Partner $29 \%$ \\
\hline & Friend $23 \%$ & \\
\hline \multicolumn{3}{|l|}{ Financial support } \\
\hline \multirow[t]{2}{*}{ SLLSY 1987} & Parents $39 \%$ & Parents $39 \%$ \\
\hline & Partner $21 \%$ & $\begin{array}{c}\text { Partner } 20 \% \\
\text { Child } 18 \%\end{array}$ \\
\hline \multirow[t]{2}{*}{ SSNRS 2002} & Friend $33 \%$ & Parents $24 \%$ \\
\hline & Parents $22 \%$ & Friend $21 \%$ \\
\hline
\end{tabular}

Changes in discussion partners are more gender specific. Women have the same discussion partners (partner and friends), categories which account for about $55 \%$ of the female respondents in both years. There were more changes for men: the variety of discussion partners (neighbor and co-worker was the most frequent, followed by partner and friends) has shrunk substantially (partner 52\% and friends $23 \%$ ) and has become more intimately oriented. The partner has become the predominant discussion partner for men (not so for women).

In provision of financial support, changes over the years are similar for men and women, as the partner disappears as a support source, i.e. a horizontal tie within the immediate family is no longer able to provide additional financial support. Vertical ties (parents and children) are still important, but for fewer respondents - they receive about $20 \%$ fewer responses than in 1987 . Both male and female respondents would seek financial support outside the immediate family - friends are more important source for men (33\%) than for women $(21 \%)$.

Differences across age groups are presented in Table 6. Let us first consider the most frequent provider of support in the case of an illness across age groups. The most frequent support provider is the same in 1987 and in 2002 across age groups. For respondents younger than 25 , the most frequent support provider in the case of an illness is the parents, and the partner for other age groups. There is only 
one significant difference in the age group 35-49, where in 2002 a child is also frequently a support provider in the case of an illness, whereas in the 1987 survey a partner is listed by $75 \%$ respondents. These results are in line with other research in Slovenia and abroad (e.g., Wellman and Wortley, 1990; Fischer, 1982; Kogovšek et al., 2003; Dremelj et al., 2004).

Table 6: Most important support providers and age groups.

\begin{tabular}{|c|c|c|c|c|c|}
\hline $\begin{array}{l}\text { Age } \\
\text { categories }\end{array}$ & $18-24$ & $25-34$ & $35-49$ & $50-64$ & $65-75$ \\
\hline \multicolumn{6}{|l|}{ Illness } \\
\hline SLLSY & Parents $60 \%$ & Partner $75 \%$ & Partner $75 \%$ & Partner 53\% & Partner $32 \%$ \\
\hline 1987 & Partner $17 \%$ & Parents $24 \%$ & & Child 33\% & $\begin{array}{c}\text { Child } 35 \% \\
\text { Other relative } \\
16 \%\end{array}$ \\
\hline SSNRS & Parents $57 \%$ & Partner $48 \%$ & Partner $55 \%$ & Partner $46 \%$ & Child 39\% \\
\hline 2002 & Friend $14 \%$ & Parents $24 \%$ & Child 15\% & Child 29\% & Partner $27 \%$ \\
\hline \multicolumn{6}{|l|}{$\begin{array}{l}\text { Discussion } \\
\text { partner }\end{array}$} \\
\hline SLLSY & Parents $31 \%$ & Partner, & Co-worker $28 \%$ & Partner 34\% & Child 33\% \\
\hline 1987 & $\begin{array}{c}\text { Partner } 22 \% \\
\text { Friend } 19 \%\end{array}$ & $\begin{array}{c}\text { friend } 24 \% \\
\text { Co-worker } \\
22 \%\end{array}$ & Partner $22 \%$ & $\begin{array}{c}\text { Friend } 26 \% \\
\text { Neighbor } \\
16 \%\end{array}$ & $\begin{array}{c}\text { Neighbor } 22 \% \\
\text { Partner, friend } \\
19 \%\end{array}$ \\
\hline SSNRS & Friend $43 \%$ & Partner $42 \%$ & Partner $50 \%$ & Partner $41 \%$ & Partner $33 \%$ \\
\hline 2002 & $\begin{array}{l}\text { Partner } 24 \% \\
\text { Parents } 19 \%\end{array}$ & Friend $31 \%$ & Friend $23 \%$ & Friend $22 \%$ & $\begin{array}{l}\text { Child } 21 \% \\
\text { Friend } 17 \%\end{array}$ \\
\hline \multicolumn{6}{|l|}{$\begin{array}{l}\text { Financial } \\
\text { support }\end{array}$} \\
\hline SLLSY & Parents $60 \%$ & Parents $50 \%$ & Partner $36 \%$ & Child $29 \%$ & Child $72 \%$ \\
\hline 1987 & Friend $21 \%$ & Partner $26 \%$ & Parents $32 \%$ & $\begin{array}{l}\text { Siblings } 24 \% \\
\text { Partner } 18 \%\end{array}$ & Partner $21 \%$ \\
\hline SSNRS & Parents $55 \%$ & Parents $39 \%$ & Friend $33 \%$ & Friend $30 \%$ & Child $39 \%$ \\
\hline 2002 & Friend $21 \%$ & Friend $25 \%$ & $\begin{array}{c}\text { Siblings } 18 \% \\
\text { Parents } 17 \% \\
\text { Other relative } \\
15 \%\end{array}$ & $\begin{array}{l}\text { Child } 19 \% \\
\text { Siblings } 16 \%\end{array}$ & $\begin{array}{l}\text { Friend } 19 \% \\
\text { Siblings } 19 \%\end{array}$ \\
\hline
\end{tabular}

There are significant changes across age groups for discussion partners in both studies. For the youngest respondents, parents, partner and friends are the most important discussion partners, but in reversed frequency distribution (in 1987 parents are the most frequent; in 2002 friends are the most frequent). At least in part these results can be attributed to the new situation of modern youth in Slovenia (e.g., Ule et al., 2000; Ule and Kuhar, 2002; Ule, 2004) - a prolonged cycle of youth due to prolonged schooling and economic dependence on parents, the rise of so-called postmodern values (e.g., family, friends, ecology). In the 1987 partner, friends and co-workers are equally frequent for the age group 25-34, whereas in 2002 the partner receives twice the frequency of 1987 (24\% - 42\%), friends about $10 \%$ more than in 1987. Co-workers and partner are the most frequent discussion partners in 1987 for the next age group (35-49), whereas in 2002 the partner is the main discussion partner for half of the respondents and 
friends for $23 \%$ of the respondents. In 1987 we have a variety of discussion partners in several age groups, whereas in 2002 there are mainly two most frequent discussion partners. For the last two age groups similar changes can be observed, as neighbors are very important in 1987, together with the partner and friends (for the age group 50-64) and children (for the age group 65-75), whereas in 2002 the partner is more frequent and neighbors are less frequent (6\% for the age group 5064 , and $10 \%$ for the age group 65-75). Together with other observed changes in discussion partners, we assume that in 1987 people were genuinely interested in the ongoing political and societal changes, whereas in 2002 life was much more stable and predictable (at least in the political sphere, if not in the economic), and family remains an important area of life for most age groups. Therefore, discussion partners are less diverse, and in general they are very important (intimate and close) others. ${ }^{17}$

There are significant differences in financial support provisions across age groups and across study years. In 1987 the immediate family was able to provide financial support to family members (even though this was still a communist regime, and people were in general poorer, but social inequalities were not as large as in 2002) as well as, parents (for the age groups $18-24,25-34,35-49$ ), the partner (for all age groups except the youngest) and children (for the age groups 50 $-64,65-75)$. In 2002 the partner is not a frequent financial support provider in any age group, friends are very frequent in all age groups (most frequent for the age groups $35-49,50-64)$, and siblings are very important for adult age groups $(35-49,50-64,65-75)$.

\section{Conclusions}

The methodological findings of this paper are not country specific and require further research attention, as the dilemma of distinguishing hypothetical from. actual providers of social support is quite frequent in designing survey questions to measure social support provision. Seven questions to evaluate social support provision using the role relation approach were tested in our study with a split ballot approach. Four questions were found to be insensitive to variation in question wording. However, two questions showed significant differences in the second support provider, and one question in both social support providers. Based on our findings, we assume that when strong ties are the main providers of social support and the number of support providers is very small, then both question wordings would yield similar, if not identical, results. However, when the number of support providers is larger and support providers are interchangeable,

${ }^{17}$ For instance, regarding the shift of values towards ever greater importance of the private sphere of family and close friends, especially among the young, see Ule et al., 2000; Ule and Kuhar, 2002; Ule, 2004. 
hypothetical and actual support providers differ. Therefore, we strongly suggest careful consideration of question wording and of the intended focus of the survey questions when asking about support providers. Further tests are needed to generalize our findings to the name generator approach and to the possible effects of hypothetical vs. actual support providers on network composition.

Evaluating changes in social support provision over time requires careful consideration of possible explanations for differences and similarities found in survey data. Special attention to survey design is necessary whenever a researcher uses secondary data collected with other than comparative intentions. We believe that indicators used in this paper to evaluate social support provision in Slovenia in the 15 year period are equivalent and enable substantive analysis of changes in social support providers. We conclude that there have been substantive changes in social support providers and that these changes vary across demographic groups. Social support providers in the case of an illness have became more dispersed; the partner - the most frequent provider of social support in 1987 - has become a less frequent provider across all demographic groups, and friends were introduced as more frequent providers in 2002. As was shown in the previous section, the educational level is rising and with it the period of relative (in)dependence on parents by younger people, who stay in school longer than in 1987. Since Slovenia is geographically very small, the majority of young people that attend higher education institutions, live at home and commute daily. In Slovenia full employment of women was already achieved during the socialist regime. At the same time, jobs had become more demanding (e.g., a lower percentage of full-time jobs; e.g., Hanžek, 1998, 1999) and women less available at home for care in cases that are not life threatening, such as the flu. As has been shown, friends are the most important help providers, apart from parents for the youngest respondents (18-24). Furthermore, the traditional division of labor within the family, with women as the main caregivers has survived the change in the socioeconomic system and become even more obvious.

Discussion partners have become less numerous and more intimate in 2002, and these changes are gender specific, with women having the same discussion partners and men losing coworkers and neighbors and focusing on partners. These changes are more difficult to explain. One can speculate that an explanation for such dramatic changes can be found in the political situation in Slovenia and Yugoslavia in 1987. There were many actual events around 1987 that could be outlined to illustrate the general situation in Slovenia. Let us mention just two of these: in 1986 the Yugoslav army started threatening to take over if the civil leadership would not lead Yugoslavia along Tito's way, and in February 1987 a special edition of the journal "Nova Revija" proposed a program for the development of a Slovenian nation in opposition to the Serbian nationalist program proposed by the Serbian Academy of Sciences and Arts. Both situations led to heated discussions in daily magazines and among people. In 1987 politics was vitally important as a discussion topic, since the turmoil, which later led to the 
independence of Slovenia and the terrible war in the Balkans, had already started in the eighties. As Slovenia is a very traditional country in many respects and women are not much interested in politics (Ferligoj et al., 1990), one possible explanation is that in 1987 the current political situation was relevant to everybody, but appeared more often in everyday discussions for male respondents. They perhaps discussed such topics with co-workers and neighbors as well as with friends and partner. Since women are traditionally more intimately oriented, they perhaps discussed similar topics, but more often with friends and partner. In 2002 politics was not as important compared to everyday life problems, with the stress and insecurity introduced along the capitalist economy, so other topics were more important for both genders, and the partner was the most important discussion partner for male respondents. Female respondents shared everyday matters equally with partner and friends in both years. However, such explanations should be read with caution, as they are based on informed speculation about the situation in 1987, and not all relevant data is available for both years. There have been changes in financial support provision with a reduction in immediate family (a smaller percentage of parents, partners and children) and the introduction of friends as very important financial support providers. It seems that increased economic inequalities are pronounced for older adults (they should be the primary financial source for adult children), who are no longer able to provide financial support.

We believe that the observed differences in support providers are substantive ones and need careful examination and delineation of transition factors (changes in Slovenia owing to the transformation of the political and socioeconomic system) from developmental factors (changes in the broader society - e.g., Europe). Therefore, conclusions and discussion should be seen as a starting point for further and more sociological explanations of the observed changes in social support provision.

\section{Acknowledgements}

The authors would like to thank the reviewers for valuable comments on earlier drafts of the paper. 


\section{References}

[1] Bailey, S. and Marsden, P.V. (1999): Interpretation and interview context: Examining the General Social Survey name generator using cognitive methods. Social Networks, 21, 287-309.

[2] Bodenhausen, G.V. and Wyer, R.S. (1987): Social cognition and social reality: Information acquisition and use in the laboratory and the real world. In Hippler, H.J., Schwarz, N., and Sudman, S. (Eds.): Social Information Processing and Survey Methodology, 6-41. New York: Springer-Verlag.

[3] Boh, K. in skupina (2000): Stratifikacija in kvaliteta življenja v Jugoslaviji 1987 [kodirna knjiga]. Ljubljana: Univerza v Ljubljani. Institut za sociologijo in filozofijo pri Univerzi v Ljubljani, 1987. Ljubljana: Univerza v Ljubljani. Arhiv družboslovnih podatkov [izdelava, distribucija], 2000.

[4] Burt, R.S. (1984): Network items in the general social survey. Social Networks, 6, 293-339.

[5] Burt, R.S. (1991): Measuring age as a structural concept. Social Networks, 13, $1-34$.

[6] Dremelj, P. (2003): Sorodstvene vezi, kot vir socialne opore posameznikov. Družboslovne razprave, 43, 149-170.

[7] Dremelj, P., Kogovšek, T., and Hlebec, V. (2004): Omrežja socialne opore prebivalstva Slovenije. In Novak, M. (Ed.): Omrežja socialne opore prebivalstva Slovenije, 47-60. Ljubljana: Inštitut Republike Slovenije za socialno varstvo.

[8] Ferligoj, A., Rener, T., and Ule, M. (1990): Ženska, zasebno, politično ali »Ne vem, sem neodločena«. Ljubljana: Znanstveno in publicistično središče.

[9] Ferligoj, A. in drugi (2002): Omrežja socialnih opor prebivalstva Slovenije. 2002 [kodirna knjiga]. Ljubljana: Fakulteta za družbene vede in Inštitut Republike Slovenije za socialno varstvo.

[10] Fischer, C.S. (1982): To Dwell among Friends. Chicago: University of Chicago Press.

[11] Granovetter, M. (1982): The strength of weak ties: A network theory revisited. In Marsden, P.V. and Lin, N. (Eds.): Social Structure and Network Analysis, 105-130. Beverly Hills: Sage.

[12] Gregorčič, M. and Hanžek, M. (Eds.) (2001): Poročilo o človekovem razvoju Slovenija 2000-2001. Ljubljana: UMAR, UNDP.

[13] Hanžek, M. (Ed.) (1998): Poročilo o človekovem razvoju Slovenija 1998. Ljubljana: UMAR, UNDP.

[14] Hanžek, M. (Ed.) (1999): Poročilo o človekovem razvoju Slovenija 1999. Ljubljana: UMAR, UNDP. 
[15] Hastie, R. (1987): Information processing theory for the survey researcher. In Hippler, H.J., Schwarz, N., and Sudman, S. (Eds.): Social Information Processing and Survey Methodology, 42-70. New York: Springer-Verlag.

[16] Hlebec, V. (2003): Omrežja starostnikov v Sloveniji. Družboslovne razprave, 43, 171-182.

[17] Hlebec, V. (2004): Socialna omrežja starostnikov. In Novak, M. (Ed.): Omrežja socialne opore prebivalstva Slovenije, 11-120. Ljubljana: Inštitut Republike Slovenije za socialno varstvo.

[18] Iglič, H. (1988): Ego-centrične socialne mreže. Družboslovne razprave, 5, 8293.

[19] Javornik, J. and Korošec, V. (Eds.): (2003): Poročilo o človekovem razvoju Slovenija 2002/03: Človekov razvoj in zdravje. Ljubljana: UMAR, UNDP.

[20] Kogovšek, T., Ferligoj, A., Coenders, G., and Saris, W.E. (2002): Estimating the reliability and validity of personal support measures: Full information ML estimation with planned incomplete data. Social Networks, 24, 1-20.

[1] Kogovšek, T. and Hlebec, V. (2005): Effects of limitation of number of alters and time frame in Burt name generator. Metodološki zvezki, 2, 59-71.

[21] Kogovšek, T., Hlebec, V., Dremelj, P., and Ferligoj, A. (2003): Omrežja socialne opore Ljubljančanov. Družboslovne razprave, 43, 183-204.

[22] Krosnick, J.A. (1991): Response strategies for coping with the cognitive demands of attitude measures in surveys. Applied Cognitive Psychology, 5, 213-236.

[23] Laireiter, A. and Baumann, U. (1992): Network structures and support functions - theoretical and empirical analyses. In Veiel, H.O.F. and Baumann, U. (Eds.): The Meaning and Measurement of Social Support, 33-56. New York: Hemisphere Publishing Corporation.

[24] Lozar Manfreda, K., Vehovar, V., and Hlebec, V. (2004): Collecting egocentred network data via the Web. Metodološki zvezki, 1, 295-321.

[25] Mandič, S., Filipovič, M., and Boškič, R. (2004): Social quality - the case of Slovenia. This article is based on Slovene national report (2004) as part of the work in the European Network on Social Quality.

[26] Marsden, P.V. (1987): Core discussion networks of Americans. American Sociological Review, 52, 122-131.

[27] van der Poel, M.G.M. (1993): Delineating personal support networks. Social Networks, 15, 49-70.

[28] van Tilburg, T. (1990): Support in close relationships: Is it better to assess the content or the type of relationships?. In Knipscheer, C.P.M. and Antonucci, T.C. (Eds.): Social Network Research: Substantive Issues and Methodological Questions, 151-160. Amsterdam: Swets and Zeitlinger. 
[29] Toš, N. in skupina (2000): Mednarodna raziskava o medčloveških stikih ISSP, Slovensko javno mnenje 2000/2. Ljubljana: Fakulteta za družbene vede, CJMMK.

[30] Toš, N. in skupina (2002): Stališča Slovencev o pridruževanju Evropski uniji in NATO - Slovensko javno mnenje 2002/1. Ljubljana: Fakulteta za družbene vede, CJMMK.

[31] Toš, N. in skupina (2003): Slovensko javno mnenje 2003/1. Ljubljana: Fakulteta za družbene vede, CJMMK.

[32] Toš, N. in skupina (2004): Mednarodna raziskava ISSP, Razumevanje vloge državljana - Slovensko javno mnenje 2003/4. Ljubljana: Fakulteta za družbene vede, CJMMK.

[33] Ule, M. (2004): Nove vrednote za novo tisočletje: spremembe življenjskih in vrednotnih orientacij mladih v Sloveniji. Teorija in praksa, 41, 352-360.

[34] Ule, M. and Kuhar, M. (2002): Sodobna mladina: izziv sprememb. In Miheljak, V. (Ed.): Mladina 2000, 39-77. Maribor: Aristej.

[35] Ule, M., Rener, T., Mencin Čeplak, M., and Tivadar, B. (2000): Socialna ranljivost mladih. Šentilj: Aristej.

[36] Vaux, A. (1988): Social Support: Theory, Research, and Intervention. New York: Praeger Publishers.

[37] Wellman, B. (1979): The community question. American Journal of Sociology, 84, 1201-1231.

[38] Wellman, B. and Wortley, S. (1990): Different strokes from different folks: community ties and social support. American Journal of Sociology, 96, 558588.

[39] Wellman, B., Carrington, P.J., and Hall, A. (1988): Networks as personal communities. In Wellman, B. and Berkowitz, S.D. (Eds.): Social Structure: A Network Approach, 130-184. London: JAI Press INC. 


\section{Appendix: Question wordings}

\section{Burt name generator}

1987: From time to time, most people discuss important personal matters with other people. Looking back over the last six months, who are the people with whom you discussed an important personal matter? Please just tell me their first names or initials.

2002: From time to time, most people discuss important personal matters with other people, for instance if they quarrel with someone, when they have problems at their work, family problems or similar. Who are the people with whom you usually discuss personal matters that are important to you?

2. Material support: One cannot complete some tasks around the house or garden by him/herself. It may happen that you need someone to hold the ladder for you or to help you to move the furniture.

3. Social support in the case of an illness: Suppose you had the flu and you had to stay in bed for a few days and needed help around the home, with shopping and such.

4. Financial support: Suppose you needed to borrow a large sum of money.

5. Trouble with partner: Suppose you have trouble with your partner (husband or wife) that you cannot solve by yourself. Who would you turn to for help or advice? Even if you are not married and you are without a partner, try to answer what you would do in a case like this.

6. Support in the case of sadness or depression: Suppose you are feeling blue, sad, or a little depressed and you would like to talk about it to someone.

7. Advice: Suppose that you need advice about a major life transition such as changing jobs or moving to another city.

1. Usual providers: Who do you usually turn to first for help? Who would you usually turn to second?

2. Hypothetical providers: Who would you turn to first for help? Who would you turn to second? 